\title{
REINVENTING OLD POWER: STATE, TRIBUTE, AND INDIANS IN PUNO
}

\author{
Christine Hunefeldt \\ Universiíy of California, San Diego
}

In 1824. toward the end of the Wars of Independence (1820-1825), Hiram Paulding, an English traveler reached Peru's Central Highlands. One ofhis stops was at the small town [villorio] of Gulcán, where he met its Gobernador and Alcalde:

"With the insistence of a desperate man, I showed the Gobernador, an old Indian, my passport for the second time, and told him to read it. [The passport was signed by General Simón Bolívar, and it ordered all state employees to provide Paulding and his co-travelers with whatever they needed]. I told the Gobernador it would be risky for him to disobey the General's orders. I requested food and horses, and assured him that the Libertador punished anyone not providing the requested items. His fears and maybe the generous amount of money I offered to pay helped him make up his mind. Suddenly, the Gobernador remembered that there were some state-owned horses at his disposal and some goats on nearby pastures. Some hours later we had horses, anew guide, and the necessary 
food to still our hunger. However, we were unable to obtain bread. When we asked for it, he emphatically answered: 'No hay.' [There is none'].

Shortly before we were ready to leave, the old Gobernador carne up to me and insisted that I take my money back. Maybe he feared official reprimands, or sensed he was disobeying superior orders. At first he had lightheartedly accepted the money I gave him, but then, after consulting for some minutes with the Alcalde, he was worried and explained that it was improper to receive the money because he was the Gobernador of Gulcán. I tried to convince him that it was not a crime or immoral to take the money, but he stubbomly insisted that I take the money back. Finally, I mounted my horse and said good-bye.

I felt perplexed at the old Indian's attitude. I had not received anything except the horses that really belonged to the state. Had he been receiving help from the state, the matter would have been different and simple. However, when he killed one of his own goats for us everything was more complicated. His authority as a Gobernador stretched over half a dozen miserable huts and he did not receive anything from the govemment. I simply could not understand why he had rejected the money, a sum of money that would have tempted any person owning more than he did"1

\footnotetext{
"Con la fuerza de un hombre desesperado, presente mi pasaporte al Gobernador por segunda vez (un viejo indio) diciéndole que lo leyera y que desobedeciera a riesgo de él. Le requerí nos proveyera de comida y caballos al instante, asegurándole venganza del Libertador por cada momento innecesario de retraso. El miedo al castigo junto con el propio interés, pudo haberlo servido de estímulo, ya que me valí de una buena remuneración como premio a su pronto cumplimiento; el Gobernador, cediendo a su timidez y al sentido de obligación oficial, recordó, de pronto, que habían caballos del Estado a su disposición y que habían cabras que pastaban los campos, cosa que nosotros no podíamos observar. De esta manera, unas horas más tarde puso a nuestras órdenes un nuevo guía y caballos, asi como los recursos alimenticios para satisfacer los apetitos de la naturaleza; a pesar de todo, no pudimos obtener pan, a cuyo requerimiento nos daban la enfática respuesta de "no hay". A poco de llegado el momento de despedirnos, nos dimos cuenta de su escrupulosa delicadeza, observando su pundonor y su miedo de ofender a los altos poderes, si es que diera la mala interpretación a su conducta. Yo había puesto en sus manos una suma de dinero como compensación por lo que había recibido, a lo cual no puso objeción en el primer momento, pero, habiendo sido aconsejado por el "Alcalde" con quien tuvo una discusión de algunos minutos, vino donde mi preocupado, diciendo que no era lícito ni propio de él recibir dinero, ya que era el Gobernador del pueblo de Gulcan. Aunque no era cuestión de formalidades con él solamente, ni era un crimen ni un deshonor aceptar el dinero, no obstante, insistía, con obstinada perseverancia, para que yo tomara el dinero de regreso. Al fin, monté mi caballo y, por última vez, le dije "adiós".

Me sentía perplejo en mis conjeturas referente a la singular terquedad del viejo indio. Yo no había recibido nada, excepto los caballos que, realmente, pertenecían al Gobierno: si él estuviera recibiendo ayuda del Estado, el asunto hubiera sido diferente y muy simple, pero desde el momento que había sacrificado una de sus cabras por mí, lodo era más complicado. Su autoridad se extendía sobre los
} 
The Gobernador's hesitations to accept money, his consultation with the Alcalde, and his reading of the passport synthesize the difficulties of state-building in the decades following the Wars of Independence. During colonial times, Indians had paid money (tribute), not received money from the state. Although Indians were widely involved in monetary transactions, and were thus well-aware of the market value of money, accepting money from the state or from one of the state's local representatives meant reversing the order of things, and implied the danger of losing ones means of survival, land and protection. Paulding, a foreigner, was perceived to be at the intersection of a prívate moneyholder - from whom it was licit to accept money - and, because he was holding a passport with the signature of the current president, he was perceived as a representative of the state - from whom it was not licit to accept money. Although the Indian Gobernador was al so part of the state bureaucracy, because he collected the tribute from the Indians living in the half dozen huts in Gulcán, the traveler with a passport signed by Peru's current president, Bolívar, was a bureaucrat of higher standing. The flow of money went upwards, not downwards: from the Indian Gobernador, alcalde, cacique, or segunda, to the district Gobernador of the district, to the Subprefecto of the province, to the Departmental Treasury (Tesorería). Both levels of "misunderstanding", - who this traveler was (a prívate money holder or a state representative) and which the Gobernador s relationship to him was (higher or lower in the state bureaucracy) - and the final option of not receiving the money from Paulding, explain the Gobernador s decisions on both issues. ${ }^{2}$

habitantes que vivían en media docena de míseras chozas y él no recibía nada del Gobierno; yo no podía descubrir el misterio de haber declinado aceptar tal cantidad de dinero, suma que hubiera tentado la codicia de cualquier persona en mejor posición que él". Colección de Documentos de la Independencia del Perú (from here on CDIP), tomo XXVII, vol. 2, Relaciones de Viajeros, Hiram Paulding, Visita a Bolívar en Huaraz, 1824.

2 What is surprising in the episode narrated by Paulding is the absence of a written record documenting the delivery of the horses belonging to the state. Usually, when an army officer requested animáis, food. or fodder for his troops. he signed a "vale" in which the delivery was registered. This "vale" could then later — when there eventually was enough money — be redeemed from the state coffers. Moreover. handing out state properly. could make Gulcan's Gobernador accountable for missing state property if he could not prove the destiny of these resources. Maybe, Paulding just forgot to mention he signed a "vale." but more probably there was no "vale". Tacitly, this means that the Gobernador handed out horses he miglit as well have kept for himself, that he did not fear governmental reprimands, and that he probably knew that the horses could never be tracked down. If he nevertheless gave the horses to Paulding without receiving money, it was the passport signed by the Libertador which explains his decisión. In doing so, he pul himself cióse to the source of povver, i.c. he saw himself as a participant in a political bargaining process. 
For Indians at the beginning of the nineteenth century, the use of money was more than a register of their level of participation in monetary markets. It was also a political and a cultural register, or as Steve Stern (1987:289) put it, "con frecuencia nuestros registros "enmascaran" la lógica cultural y la función social de las intervenciones mercantiles andinas". ["Often our understanding of things mask the cultural logic and the social role of Andean merchantile participation"]. Money paid to the state had a different value than money used in market transactions.

Much has been written about the tribute paid by Indians to the colonial state, and the meaning of the tribute in the wider contexts of colonial economic relationships, and the relationships between Indian peasants and the state. It has been stated that the tribute — tied to the silver production in Potosí — was a key element in dynamizing the internal colonial market, and in incorporating the Indian "ethnic economy" into the Spanish market economy (Assadourian, 1983; MacLeod, 1984:219-264). When analyzing the relationship between peasants and the state, the dependency of the colonial state on the tribute payments has been underlined, as has - for the colonial period, and also for the Republican Bolivian state (Platt, 1982; 1987:99-100) - the idea of a tacit agreement between state and peasantry: tribute payments represented the guarantee of the state's defense of Indian lands. Thus, the main reason why peasants were willing to pay tribute was this tacit agreement.

From a microlevel perspective (Puno, 1825-1845), I will argue that Puno's Indians peasants rebuilt their perception of state hierarchies and their own relationship to the state, by interacting with the state's local representatives (Gobernadores and Subprefectos) on a daily basis. In the power vacuum resulting from the Wars of Independence, peasants observed Gobernadores and Subprefectos handle "state matters", especially tribute payments. Tributes represented the heart of the nexus between the state, local powerholders, and Indian peasants. The "tacit agreement" between state and Indian peasants was mediated by a complex web of power relations. If there had ever existed a "tacit agreement", Puno's history in the first decades after Independence was the systematic dismantlement of any such agreement.

By describing the multiple uses and abuses of tribute payments, I want to illustrate how the access to Indian tribute, was important in a sheer quantitative sense for the new Republican state, but also to the reconstruction of local power relations, 
and to define the relationship between local (provincial and distrital) powerholders vis-a-vis Lima's centralizing tendencias. ${ }^{3}$ Indian peasants had a saying in the reshaping of local power relations, and in doing so, in defining the relationship between local elites and the Peruvian state. In interpreting these multilayered relationships we can understand the changing circumstances under which Indian peasants were willing and or-increasingly so-forced to forward payments to a state unable and unwilling to grant any kind or protection. The spectacle of factionalism and peasants' actions, in tum, also dismantles the longheld image of Indians' political mutism and their retreat into self-subsistence.

\section{THE REPUBLICAN STATE AND THE INDIAN TRIBUTE}

The burden of the Wars of Independence (1820-1825) was carried by peasants. Troops from both sides (patriotic and royalist) more than once looted peasants' crops and animals for "war purposes", and recruited soldiers among peasants. In Junín and Ayacucho - the two battlesites where the Independence from Spain was sealed in 1825 - 30,000 men fought under the leadership of General Simón Bolívar, on one side, and Viceroy Pezuela, on the other. ${ }^{4}$

In following the various subtitles of Basadre's Historia de la República for the first half of the nineteenth century, one realizes the dimensions of Peru's political instability in this period: the end of Simón Bolívar s "lifelong" presidential mandate, liberal constitutionalism between 1827 and 1828, military authoritariansm between 1829 and 1833, civil strife between 1833 and 1836, the Peruvian-Bolivian Confederatíon (1836-1839), Restauration followed by new military confrontations. In each períod, more than one candidate disputed the presidency of the Peruvian state ${ }^{5}$ The count of various kinds of govemment documents political unrest, and unrest went hand in hand with what by all accounts was a weak state. In 1828, the

\footnotetext{
3 Puno's history during this lime period contradicts Veliz's (1984) assertions concerning the "centralist tradition in Latín America". It of course also depends on how we define centralism, and the "discovery" of subaltern resistance makes this deflnition especially difficult.

4 And, this number does not include the montoneras in many towns and communties on the coast and in the highlands, the many women who went with the troops. or the occasional goat for a European traveler.

5 Massive uprooting, empty fields, and fiscal disaster was the bill of five years of war. According to Basadre, in this time period there were "tres asambleas constituyentes", "seis intentonas de regímenes constitucionales en diez y ocho años y tres autoritarias".
} 
Peruvian president counted only on four edecanes and two capellanes, and there were only three Ministers: Government and Foreign Affairs (Gobierno y Relaciones Exteriores), War and Marine (Guerra y Marina), Economic Affairs (Hacienda), with 11,13, and 12 employees respectively (Basadre, 1961:438 and 195). Many more state employees existed in the provinces, over whom Lima's government had little or no control, because it had no money to pay for employees' salaries. The "salaries" Gobernadores, Subprefectos, and Prefectos largely depended on what they could exact from peasants under their tutelage. Thus, the "salary level" depended on the ability to impose exactions on peasants, and ability in turn depended on how peasants perceived these state employees (legitimacy), the local support networks these state employees could rely on (class alliances), the information on local production (control), and the availability of guns (enforcement mechanisms). These characteristics were not a given, but terrains of contestation.

Between 1826 and 1854 the expected total annual average of tribute payments from all regions in Peru was 1'300.000 pesos, that is, approximately 20 percent of the state's revenues. Around 1850, the tribute represented not only about 25 percent of the national budget, but also 100 percent of departmental budgets (Kubler, 1952). In a peak year like 1847 , the percentage of the contribucion indigena of the total direct fiscal revenues came close to 85 percent of the total budget. ${ }^{6}$ In other words, the Republican state depended on Indian tributes as much as the colonial state had, and it comes as no surprise that in the years following Independence, provincial political and economic life, and state policies revolved around the access to tribute payments. Although the continued existence of a headtax based on race was perceived as an "abominable colonial remnant" in liberal rhetoric, fiscal necessity overrode such rhetoric. The tribute underwent intense debate and reformulation, but no matter how contribución was defined after 1825 in successive decrees, in essence it matched the colonial Indian tribute?

That year from a total of 1'569.084 pesos of fiscal revenues, 1'326.931 pesos came from contribusción indigena (Basadre, 1968-70; Piel, 1982).

7 Unjess specificied differently in the wake of legal definitions and debates, I will use "tribute" as meaning the headtax paid by Indians, especially because as will be clear throughout, it were the amounts of headtax that were paid throughout the century in spite of the rhetoric to the contrary, and in spite of the formal abolition of the Indian tribute in 1854. The forms changed, but the meaning and the amounts paid remained the same. 
In 1821, General San Martín established two kinds of contribuciones, one secular, one ecclesiastical. Each Departamento had to pay a given sum of money on a monthly basis. In reaction to San Martín's decree, the Juntas de Municipalidadin which the local notables participated—summoned in each departamental capital to evaluate who produced what and, consequently, assign who would have to pay how much to fulfill the quota. The Junta then recommended the Gobernadores (called Intendentes in 1821) to do the same intheir jurisdictions, and Gobernadores, in turn, were to summon provincial municipal juntas to do the same. For the contribución eclesiástica, instead of Gobernadores, Vicars had to organize payments. While Gobernadores and Vicars elaborated the lists of contributors based on what they knew about the property and income of individuals in their neighborhoods, the Subprefectos and the Prefecto exerted continued pressure to access the expected revenues. However, in December 1823 the rules changed. Following a Bolivarian decree, everyone was requested to pay the contribución única. When the members of the municipality met to discuss the new decree, they unanimously decided it was unrealistic: the implementation of the decree would substantially diminish fiscal revenues because production sites and levels on the coast were different from those in the highlands. The municipalities forwarded their thoughts to Bolívar, but by 1826 they were still awaiting an answer. Instead of a direct answer another decree was published. Now, there should be no contribución única, but a contribución rústica, and a contribución urbana. Thus the municipality's geographic-production concern was answered with a rural-urban dichotomy based on property. Any property tax presupposes the existence of property in the first place and then, also knowing what a property consisted of, and how much it was worth. In an economic setting where urban "industrial" workshops were family-owned, and where rural property was hazy because communal and prívate posession of land overlapped, and the value of an hacienda was assessed in terms of the amount of workers it could eventually draw, determining the boundaries and the value of individual property was, indeed, unrealistic. Even if the attempt was made to impose a property tax (in contrast to a headtax), much time would elapse until new tax registers were ready. Somewhat aware of the difficulties involved, the 1823 decree stipulated that until the new registers (matrículas) existed, everyone had to pay the contribución corriente, that is, everything should remain the same until it was possible to do otherwise. 
The first new matrículas sent to the Departmental Treasury were returned because they did not specify what each property produced. When months later some corrected listings reached the Treasury once again, a new Supreme Decree (Decreto Surpremo) ordered that the percentage of tax on the total assessed value of each property be lowered. Consequently, the lists carne back for adjustments for a second time.

In only fíve years, between 1821 and 1826, three different decrees concerning contribuciones were published, and each required a reversal of actions taken to implement the prior one. From these experiences, local authorities soon learned that any attempt to change the tax structure was an impossible undertaking and a waste of time. When confronted with state-issued decrees, municipalities and Gobernadores began arguing that more able people were needed to carry out tributary reforms, and that most peasant plots were so small they were not worth the paper they were registered on. From this dialogue between state-sponsored liberal ideas and local powerholders well aware of local reality and their own interests, soon, aconsensus evolved: areformulated contribución única was the preferred alternative. "Reformulation"—as deviced by local authorities_-meant that "the Peruvians [!] who were tríbutaries under Spanish rule continue paying what they always had", that those from other "classes" with no property or known trade, that is, those who had to sell their labor force, pay the same as the first, and that those who had landed property (finca and hacienda owners, not peasants), or public industrial workshops (talleres) pay a percentage of their revenues. In this version, Peru's ethnic social structure had a tax counterpart: headtax for Indians, property tax for white hacieda owners, income tax for all others. "Peruvians" - in this text-were, of course, Indians; those who sold their labor force were Mestizos and Castas; those who owned large estates were whites. Quite straightforwardly the wording was a disguise to protract the contribución indígena and the contribución de castas. To implement these "changes", Visitadores should be sent out to each province to renew the matrículas, "following the oíd matriculas" ("a manera de las matrículas antiguas"), that is, the colonial matrículas. Because it was not entirely safe to trust the Visitadores, Gobernadores and priests should help to elaborate the lists.

State policies and intentions, and local perceptions ran in opposite directions. Decree after decree reached the Prefecturas to enforce new taxes and demand higher efficiency. Local authorities responded by demonstrating the decrees' inviability and criticizing the changes: 
"we see continuous decrees and orders coming from Limahaving something to do with contributions, but those who issue these decrees have no idea about the desolation, the miseries, and the poverty in these pueblos after such a long and devastating war. This war left no untouched interstice on the whole continentOne of the most dramatic consequences of the War is that it has uprooted people forcing them to wander around, and with no place to go, maybe with the exception of the indigenous population. But even among Indians there are many who have hit the road and left their homes, in spite of their strong attachment to their land. And, if this is happening to Indians, how much more must those suffer who are not Indians. Not being used to pay any kind of contributions, but still being subjected to recruitment, the non-Indians prefer to embrace the life of savages, or untamed animals, moving from one place to the next, from one province to another, without the recaudadores having any means to assure they pay a contribution". 8

The chronology of fiscal reforms and the answers from members of the municipality, Gobernadores, and Subprefectos show the impasses of a liberal agenda during and after the Wars of Independence. What carne out of this dialogue between Lima's governments and local powerholders was the recognition that whatever the government proposed was worse than the colonial fiscal system. The most efficient way to collect contribuciones was the colonial way.

On August 11,1826, a decree ruled that Indians between 18 and 50 years old liad to pay the same amounts as in 1820. Thus, the contribución - this time explicitly — was again the colonial Iridian tribute. However, (and this was the only "liberal compromise") when the tax on property was higher than the "personal tax", Indians, as everyone else, were required to pay 4 percent on the value of the property orindustry. ${ }^{9}$ To give tax collectors incentives, Gobernadores were allowed to retain 2 percent of the total tribute collected in the districts, and Subprefectos were allowed 4 percent. These percentages were also meant to pay for their salaries, the state was unable to provide. It meant: the "harvest economy" reinstalled. ${ }^{10}$

8 Archivo de la Prefectura de Puno (from hereon APPu), Report from Anselmo Vera. Subprefecto of Abancay, 1829.

9 APPu, B-224 [these numbers correspond to my own listings. The Prefectural archive - until I arrived in Puno - was a heap of unsorted dirty papers], copy of mentioned decree.

10 Very adequately MacLeod (1984:219-264) has called this a "harvest economy", an option that in colonial times and afterwards greatly diminished the state's control on regional politics and economic performance. 
New problems soon surfaced. On June 9,1831, José Serna of the Contaduría General de Contribuciones advised the Ministro de Hacienda of the difficulties involved:

"The smallest Indian personal tax in the whole Republic is never less than 12 reales each semester [...]. The personal tax of all other castas is always the same, not more and not less than 12 reales. If - following the law-Indians or castas pay this same amount or more, they do not have to pay the personal tax anymore. The tax on property or industry is stipulated at 4 percent, thus, to pay 8 reales each semester, the individual needs to earn 50 pesos a year. In other words, in most cases [including Indians, castas, and even the military and bureaucrats] individuals would be paying a personal tax, because it is higher than the 4 percent of their income or property value". ${ }^{1}$

But, "all the others" were not used to pay a personal tax, or had never paid direct taxes at all. Moreover, the personal tax was attached to índianness, and most people - especially mestizos and castas — rejected being fiscally treated like Indians. Beyond perceptions and self-perceptions, many castas had no fixed jobs, or land, something that made it difficult for tax collectors to get a hold of any stipulated tax, or even of the taxpayer himself. Physical mobility and occupational instability were — on the other hand — also mechanisms to evade tax payments. A reaction to these fiscal changes was recorded by the Junta Departamental in Cusco in 1832. ${ }^{12}$ The contribuyentes - the Junta argued — were "doomed to leave their places of residence, abandon their families, their pueblos, and homes; and, what for? .... to peregrinate, and to become vagabonds in other pueblos, and then not doing anything they increase the number of thieves and good-for-nothings [fascinerosos]". And, the Junta members added, "this is the dire picture that the experience and the practice have conveyed as the inevitable consequence of implementing the contribución de castas". The contribución de castas was abolished on June 16,1829, but the contribución indígena was reiterated by a decree issued by the Coronel de Ejército of Cusco the same day. ${ }^{13}$

\footnotetext{
11 Archivo General de la Nación (from hereon AGN), Ministerio de Hacienda, Contaduria General de Contribuciones, O.L. 216:612-655.

12 Biblioteca Nacional (from hereon BN), D 10763, Expediente sobre abolirse la contribución de castas.

13 The comments of Anta's Subprefecto and the decrees of Cusco's Prefecto were published in El Sol del Cuzco, no. 221, tomo 5, March 21, 1829, p. 49.
} 


\section{Beyond uprooting and misery, the state's own insecurities had much to do with its empty coffers. Often, contradictory or changing rules of how to fabrícate contributions hampered many (sometimes well-intentioned) efforts carried out by local authorities. Eventually they grew tired of watching these changes, and with it, the dismantling of their efforts inprevious months or years. ${ }^{14}$}

\footnotetext{
14 An especially dramatic representation of the meaning of the state"s backs and forths is illustrated in the description of Ramón de Echenique of vvhat had happened between 1821 and 1826 in Junín, vvhen answering to three points brought up by the Consejo de Gobierno, and seemingly sent to all Prefecturas. He wrote: "Al primero: que hay dos claces de contribucion, una secular, y otra Eclesiástica, ambas individuales, y arbitrarias. Estas se mandaron establecer en Noviembre del año 21 por el Grl. Protector, que asignó al Departamento de Huaylas. cuya capital entonces era Huaraz, la cantidad de 10.000 ps. mensuales. Para arreglar esta contribución el ex-Presidente Sor. José de Rivadeneira hizo una Junta de la Municipalidad y vecinos principales de Hitarás, conocedores de las demas Provincias, y por un calculo que formaron con respecto á un Comercio y producciones les asignó la cantidad que tuvo por conveniente a fin de completar los expresados 10.000 ps mensuales. Comunicada esta resolución a los Gobernadores, que ahora son Intendentes, estos cuidaron de hacer igual operacion reuniendo a sus Municipalidades. El mismo método se observó para imponer la contribucion Eclesiastica, haciendo saver á los Vicarios de Provincia la cantidad que por cada una debían contribuir, y desde entonces la Prefectura no há cuidado demas, que de reconvenir a los Intendentes por el total de su continjente, estos a los Gobernadores, y estos ultimos a las Municipalidades, haciendose los enteros gradualmente hasta llegar á la Caja Departamental.

El cobro se hace por medio de listas que tienen los Cobradores, firmadas por los Gobernadores y revisadas por los Intendentes.

Por Diziembre del año 23 entró al mando el coronel Alcazar con el Titulo de Prefecto, en cuyo tiempo bino la orden para que se estableciese el proyecto de unica contribución sancionada en Bolívar: Sé hizo junta de la Municipalidad, y vecinos del primer rango, e instruidos de dicho proyecto declararon unánimes, que era inverificable, sin mucha perdida de los ingresos del Estado, con respecto a lo que producía la actual contribucion: pues el producto de los predios urbanos y rusticos en la Cierra de ningun modo era comparable con los de la Costa, a donde acaso habían estendido solamente sus miras los proyectistas y que sobre todo se hiciese ver al Supremo Gobierno esta notable diferencia, y si estubiese á su resolucion. Asi se verificó por el Prefecto Alcazar y no ha habido contextacion hasta la fecha. En el mismo año se agregaron al Departamento las Provincias de Jauja y Pasco [=cambios administrativos-jurisdiccionales], y el Sr. Grl. Prefecto Pardo de Zela les impuso el contingente que le pareció, segun el cálculo que formó para sí. De aquí resultó el ascender la contribución secular y Ecca. a la cantidad de 20.370 pesos mensuales.

En seguida se mandó por el Supremo Gobierno poner en práctica el proyecto de contribución de predios urbanos y rústicos. Sé dirijieron por la Prefectura las circulares a los Intendentes, para que prosediesen con peritos los abaluos y remitiesen a la Prefectura los Documentos, para dirijirlos a la Superioridad, con animo de hacerle ver por un informe la deficiencia del caudal del Fisco, si se adoptaba el proyecto de predios en este Departamento: y que entre tanto nó cesase el cobro de la contribucion corriente hasta que el Supremo Gobierno resolviese sobre su materia.

No ha llegado este caso, pues los primeros abaluos que remitieron algunos Intendentes, fueron devueltos por el Supremo Gobierno, previniendo se acompañasen con un estado, ó manifiesto jeneral, que resumase sus productos.

Sé remitieron a los Intendentes para el efecto, y ya principiaban á mandar a la Prefectura sus abaluos en el modo indicado, cuando por Supremo Decreto se declaró una rebaja en la exaccion de predios. Con este motivo se les devolvieron sus abaluos, para que los modificasen, y aun nó han despachado, sin embargo de que no cesan las reconvenciones de la Prefectura; pero no puedo dejar de hacer presente á VS que el proyecto de Contribucion de predios parese inverificable: porque según se ha visto por los
} 
Land and tribute went hand in hand in the discussions among local powerholders and members of the Congress. A "liberal fiare" was there, but it only lasted for about five years after independence, in the wake of which, fiscal necessity and image building, excluded Indians from liberal reforms, access to land, and citizenship, and sometimes even increased their tax burden to unprecedented heights.

For eleven years since 1821, Indian peasants in Chucuito paid both the contribución rústica and the contribución personal, that is, 100.000 pesos above what the matrículas stipulated. This amount, "went into the pockets of caciques, subprefectos, priests, etc., without the Indians ever opening their mouths". ${ }^{15}$ In Chucuito, the annual rent paid by its 30 haciendas and all the ecclesiastical properties apportioned only 200 pesos a year. If the Indians paid an excess of 100.000 pesos in eleven years, this means that each year they paid 50 times more than priests and hacendados together. In other words, there are indications that Indians continued to pay the tribute, large amounts of tribute payments never reached the Tesorería, and new forms of peasant extorsion evolved from the government's tribulations, vacillations, and distance.

Bolívar was aware that to implement liberal ideals, many other aspects of the political structure as well as of the production process had to change. Firsthand, through his military experiences in the Andes, he had observed Peru 's urban and rural life.

primeros Cuadernos la mayor parte de ellos, consta de Cuartillos, y otros quebrados de esta naturaleza, que para formar un entero, causaría mucha labor, se necesitarían de muchas manos auciliares, resultando al fin que no llegaría á abanzar, ni a la mitad de la Contribución corriente: á pesar de hallarse en el día en 10.130 ps. desde Enero del presente año [=7 months].

A lo segundo [deuda de contribuciones de Enero 1825 a Julio 1826] ...deben las Provincias desde el tiempo de su impocision, hasta la fecha 137.102 ps 6 reales [...]

A la tercera digo: que la clase de contribucion unica que me parese mas productiva, adaptable a los Pueblos, y facil de recaudar, en que cantidad y sobre que bases, es la de que los Peruanos que eran de la clase de Contribuyentes en el Gobierno Monarquico, paguen una tercia parte menos de lo que pagaban en aquella epoca; que los de las otras Clases que no tubiesen bienes raíces, u otro giro conocido, que constituyan sus fortunas, sino solo su trabajo personal; paguen lo mismo que los primeros; que los que tubiesen fincas, $y$ talleres publicos de industria, paguen un tanto á proporcion de lo que estos les pueda producir; que el cobro y entero de los productos, sé haga por semestres, pues estoy cierto que al menos la clase peruana mejor sé conforma con pagar el duplo semestral, que no cualquiera cantidad por exigua que sea, siempre que se la cobren al mes: y, sobre todo, que para arreglar esta contribucion debe nombrarse por el Supremos Gobierno un Vicitador en cada Provincia, que haga una nomenclatura, y taza á manera de las matrículas antiguas, en union de los Intendentes y Parrocos; no pudiendo fiarse esta operación á solos los Intendentes, porque acaso saldría imperfecta,.."'.

15 APPu, document 234, Report from the Visitador, 1832. 
His initial attempts of reform were to resettle people, especially soldiers, uprooted and dispersed all over the country because of military recruitment, and to créate prívate property and a land market based on land distribution. Only then, a restructuring of tax impositions would become viable. However, seeking fiscal remedies by changing land tenure pattems hit the substance of local power relations, especially when changes involved Indians. Local powerholders resisted land redistribution as much, if not more, as they resisted tax reforms. Responses to the implementation of land reforn showthe systematic dismantlement of any effort in that direction, either because — so ran the arguments - they contradicted longstanding traditions and thus unleashed social unrest, or because these traditions were invoked by those who did not want or know how to operate reforms.

On January 27,1825, Bolívar decreed that recruitment for the military should stop, to allow everyone to peacefully engage in agriculture and industry, and to avoid that those hiding or not venturing to return to their pueblos because of the fear of recruitment for the army, would eventually come back. ${ }^{16}$ Bringing people back to their pueblos was essential to politically and economically stabilize the country.

Even earlier, in 1824, a nationwide measuring of land should have taken place, geared toward redistributing land belonging to Spaniards who had left the country and to caciques. The government wanted to know how much "empty" land there was, and to reallocate these lands to those who were without it. ${ }^{17}$ In 1825, Bolívar "abolished" peasant communities, and cacicazgos, ${ }^{18}$ the strongholds of ethnic production, in an attempt to create prívate land ownership and distribute land, especially to forasteros.

\footnotetext{
${ }^{16}$ Decree published in El Sol del Cuzco, no. 18, p. 87, April 4, 1825.

${ }^{17}$ A close Iook at the Expedientes de Reconocimiento de Comunidades, forwarded by peasant communities in the 1920s, and kept in the Dirección de Comunidades of the Ministerio de Agricultura, that still await their recognition in large part because of the difficulties in defining their boundaries. gives an idea about how impossible this endeavour might have bcen in the early nineteenth century. Not even the deep agrarian reform promoted by General Velasco between 1968 and 1973 has solved this problem.

${ }^{18}$ The partial abolition of cacicazgos had already been decreed in 1783, as a consequence of the Tupac Amaru II rebellion. By then, neither viceroys, nor Gobernadores, nor judges could approve the creation of nevv cacicazgos, and only those already in existence would be kept, and only when they "had deserved" this privilege because of their loyalty to the king" (García Calderón, 1876:316).
} 
In Congress, two projects to distribute land were discussed, one published in Trujillo on April 8,1824, and another in Cusco, on July 4,1825. ${ }^{19}$ These projects envisaged to grant land to Indians who had none, but without expropiating those who legally possessed land, in order to - the projectread-"avoid disturbances". Soon it was recognized that many Indians, especially forasteros, had no land, and thus could not be compelled to pay tribute. Thus, an effort was made to give them access to land. In November 1826 a circular was sent to the Intendentes (=Gobernadores), ordering them to carry out a census "without reservations", that is informing exactly how much communal land was cultivated by each cacique. After this had been established, and when there was available land, land in "appropriate proportion" should go to forasteros. To safeguard any "misallocation", this circular also mentioned that errors could be rectified during a subsequent Revisita. $^{20}$

In the few instances land reform projects were implemented, its consequences carne under fíre only a few years later. An observer from Cusco, who had himself participated in the 1824 and 1825 land reform projects, in 1827 repentfully concluded that the "philanthropy and humanity that had underlied the good intentions" of handing land to Indian peasants, had had detrimental effects on índians. Neither project granted índians the actual ownership of land. Property rights were limited: índians who gained access to land were not allowed to sell it before 1850, because it was hoped that by then the "clase indijena" would be better aware of its legal rights and have learned to manage their property, a discernment - according to the projects - they utterly lacked. In spite of such "thoughtful" limitations on property rights, the observer from Cusco thought that the "attempt of benefítting the índians needs to be revised, because if we think

19 The proponents of these two projects were the deputees Don José Manuel Nocheto and Don Anselmo Quiros. These comments were published as a "Remitido Interesante", in El Sol del Cuzco, no. 142, t. 3, September 15, 1827. The commentator was well aware of peasant differentiation, and knew that an "equal" contribution of 4 pesos a year sometimes was all a piece of land was worth, whereas there were other landowners (including Indian peasants) whose lands were larger and more productive. For them 4 pesos a year represented a "nimiedad". And. this taxation-differentiation dilemma was not solved in 1827, ñor had it been solved at the end of the century. What is noteworthy also is that he was aware of differentiation, but when it carne to construct a justificatory rhetoric, all índians were equal. Homogcnizing the "other" has been a longstanding practice to exert power and enact discrimination (see Mallon, 1996).

${ }^{20}$ This circular was signed by A. Gamarra, Prefecto of Cusco in 1826. The circular was published in El Sol del Cuzco, no. 102, 12/9/1826, p. 198. 
about the longterm implications of it, combined with an assessment of the Indians' character, I am convinced that only bad things will result. There will not be a single Indian who will not sell his plot of land as soon as possible, and in less than ten years they will find themselves destitute from their main source of subsistence. Then, they will become vagabonds and err around, and it will be impossible to make them pay the contribución. The only thing that keeps them were they are is the small portions of land they cultívate with their own hands". Although the projects also stipulated that Indians could not sell land without a prior judicial report stating that is was absolutely necessary to do so, this - the observer commented-did not prevent Indians from selling their land: "the person who really wants to sell his land finds thousands of pretexts, and witnesses who will support him out of loyalty or because they have been bribed". To further underline his argument, V.L. [the anonymous writer of this article] commented that similar restrictions on land transactions had existed in the Ley 27, título 6to of the Recopilación de Indias. In spite of the strict enforcement of the Ley, Indians had always managed to sell land with ease. So, the commentator concluded, judicial intervention was inefficient, and it was to the Indians' and the state's best interest "not to benefit them [the Indians] with absolute property rights [con el don de la propiedad absoluta]". Thus, Indians were denied what they had never had. Furthermore, V.L. proposed not to distribute excess land at all, but that the state built a land reserve to enable it to distribute it as need arose. Since Revisitas and new matriculas every five years would register new tributaries as a result of demographic growth, land retention would allow the state to allocate land in exchange for contribuciones. In short, the "land question" (=Indian question) was a lukewarm attempt of land reform, and was understood as a means to exert state control and collect taxes. Very quickly. Bolivar's "land market" became a "regulated market" along ethnic lines for fiscal purposes. From philantropy the argument moved to necessity, and necessity meant protecting the privileges of local powerholders in the name of Indians' lack of understanding of their own best interest.

Parallel to the shift from philantropy to necessity, a decree of July 4,1825, caciques [here equated with 'cobradores'] were ripped of their titles, authority, and land. The initial justification for this decree was that caciques extorted Indian peasants. However, quite soon, the state and local authorities realized that without cacique-cobradores, there were no tributes. Thus, former "extortioners" became tender and paternal guardians of Indians' happiness. On February 9,1828, El Sol del Cuzco endorsed this reinterpretation of the caciques' role and behavior: 
"We well know that the caciques, also called cobradores, are the men who get the Iridian contributions for the state. In past times, these caciques were obeyed and respected by their Indians, like a child obeys and respects its father, because the caciques contributed to the happiness of these people, both in Heaven and here on Earth. They were the fathers, judges, and priests. Fathers because through tenderness they provided peace; judges because they corrected their faults and solved family quarrels; and, as priests in therayllus and parcialidades they induced them to follow the divine precepts. From here it follows that caciques contributed to the wellbeing of the nation. [...] Today we see otherwise. Today Pemvians [!] hold these positions, and they live outside the parcialidad' or the ayllu, and the collection of the tribute is in the hands of the mandones or segundas. The result is that now, Indians live in their ayllus in disarray, mingled with unruly people [malvados] that pervert them. Consequently, Indians have forgotten about God's precepts, and neglected their pasture lands; and, this is the reason why they no longer fulfill their tax obligations. The former caciques or cobradores are only interested in their prívate businesses, like the mingas on their lands, and other services they still receive from Indians because they are caciques". ${ }^{21}$

The columnist added, that he had nothing against "Peruvians" or Indians being caciques or cobradores, but that it was necessary to "materially move" the parcialidades and ayllus, and thatto accomplish this it was necessary that whoever was in charge reside in the ayllus. Residence and patemalism were key to effectively make Indians pay. With the dismissal of the caciques an important link in the tributary structure was lost, and Indian peasants did no longer fulfill their duties as citizens of the new Republican order. The measurable "damage to the nation" represented one-fifth of its annual budget, and this was a decisive argument to advocate for the reinstallment of the caciques.

Even such visible political figures like the Subprefecto of Calca, Don José Mariano Pumacahua Almanza y García, the son of Mateo Pumacahua, leader of the 1814-1815 Indian-criollo upheaval against Spain, in 1828 carne under public scrutiny and was publicly accused of continuingto demand colonial payments ("extorsions y obensiones coloniales") from Indians and vecinos. ${ }^{22}$ Caciques, in spite of Bolívar's

\footnotetext{
$\overline{{ }^{21} \text { El Sol del Cuzco, no. 173, t. 4. February 9, } 1828 .}$

${ }^{22}$ This accusation was published under "Verdades Desnudas" in El Sol del Cuzco, tomo 4, 1828, no page no.
} 
abolition decree, still held power and controlled communal resources. Now, however, attacks against Iridian caciques were staged accusing them of what everyone was doing anyway: return to colonial forms of tribute exaction.

Still, by 1838, the Subprefecto of Chucuito, Esteves, following arequest from the Gobernadores of Pomata and Acora (Rafael Loza and Manuel Catacora) based on a Decreto Supremo of August 29,1836, denounced portions of land formerly in the hands of Caciques. The 36 plots of land under scrutiny in Pomata were located inside the ayllus. Those in Acora had been rented in previous years to Vísente Vasquez, the son of a former Cacique. Until 1836, Vasquez paid rent; in 1837 and 1838 he refused to pay, arguing that the fincas had belonged to his father. However, he had no documents to prove his assertion, and the fincas were "nationalized". ${ }^{23}$ As the abolition of cacicazgos brought with it an opportunity to gain access to cacical land (especially if no land distribution for Indians followed), a tension between fiscal priorities and land ownership wishes arose that explains the "slow death" of caciques.

The difficulties in collecting tributes mentioned by V.L. were true, and rooted in how tribute was collected within ayllus orparcialidades. Tributes were not a once-in-a-time payment; they were registered almost daily in very small amounts of money, in the forra of actual money or in the monetary equivalent of producís or labor received. The Indian tribute - a contemporary observer commented - "is paid in the course of a semester following an age-old custom. The cobradores receive small amounts of five, ten, or twenty centavos each week from each tributary. Thus the coilection of the tribute for one semester at least takes five months in each semester". ${ }^{24}$ Without living in the ayllu or parcialidad a. weekly, or daily, coilection of small tribute payments was impossible, and so was the control on -.vhat Indians* produced and eventually were able to pay as tribute, and the draft oflabor.

Following earlier recommendations forwarded by municipalities, in 1827, Visitadores were in fact send to the Departments. However, their task was not to elaborate new matrículas based on the reformulation of the contribución única,

${ }^{23} \mathrm{APPu}$. 1838-1843, document 311. request from mentioned gobernadores. $\quad{ }^{24} \mathrm{BN}$. D 4569; and APPu, document 701. 
but rather to make Gobernadores and Subprefectos pay outstanding and long accumulated debts to the state. As nothing seemed to work, fiscal desperation replaced reform attempts by judicial proceedings and prisons, and increased pressure on Indian peasants.

\section{THE FISCAL GAP AND THE SUBPREFECTOS}

Fiscal gaps and uncertainties preceded the declaration of independence in 1825. Debts had mounted in the wake of the liberal constitution of 1810, which as long as it lasted (1810-1815), abolished the Indian tribute. In 1827, when the Visitador and General Commissioner of the Ministry of Economics (Visitador y Comisionado General de Hacienda) visited Puno's Treasury Office, he noted that pending debts in the Libro Mayor of the Administración were due to the partial implementation of the 1810 constitution of Cádiz:

"When in 1811 the Supremo Consejo [de Indias] abolished the Indian tribute, some of the pueblos in Puno offered to voluntarily continue paying the tribute. The Subdelegados then received these voluntary contributions. In 1812, however, the Spanish Viceroy [La Serna] following the Acta de Tribunales y Ministros of July 11,1812 , ordered that the tribute should be paid, and for this reason, the Subdelegados saw their debts increase, because from that moment onwards they were made accountable for unpaid tributes according to the oíd matriculas. The Subdelegados were held accountable until they forwarded razones juradas, and the accounting office cleared their debts. Some Subdelegados cancelled their debts, others did not. For this reason, and because of the general circumstances many Subdelegados did not have a chance to regularize their accounts, today we find these huge debts in the accounting books, debts that really are chimerical".

Thus, unpaid tributes predated independence. ${ }^{25}$ Between 1811 and 1818 the total registered amount of debt for Puno was 383.963 pesos and 4 1/2 reales. Even when subtracting "chimerical debts", that is, those the Visitador knew were unrecoverable bécause there had been bad harvests or because those responsible

${ }^{25}$ Also see Choquehuanca (1833), Jacobsen (1982), Tamayo Herrera (1982:76). 
were no longer around, Puno still owed — up to the semester of San Juan 1826 - 107.612 pesos and 3 1/2 reales for Indian tribute, out of a total of 250.442 pesos and 3 reales, of its total fiscal debt. Thus, about 43 percent of Puno's departmental debt to the state were Indian tributes.

The Visita carne along with an unrelenting persecution of the Subprefectos (the former Subdelegados), responsible for entering tribute payments to the Tesorería. Subprefectos, in turn, depended on distrital Gobernadores to collect the tribute from caciques-cobradores in smaller units (parcialidades, ayllus). While trying to impose fiscal order, the government also restructured how and when the Subprefectos had to collect the tribute. Thus, the state's efforts to recover unpaid debts affected local power relations and its effects went all the way into the homes of peasant families.

To restructure the collection of fiscal revenues, the state recommended that Subprefectos and the cobradores they chose, should "proceed to collect the tribute with softness, without using force, so that the tribute would provoke hatred from those obliged to pay it". However, Subprefectos could, if necessary, proceed against those who did not pay in time [morosos] by seizing and auctioning their belongings or sending them tojail. Subprefectos were not allowed to change matrículas on their own account and without the approval of the Contaduría General de Contribuciones, the Prefectura, and - if none of these entities could be consulted - the Presidency itself (Casa de Gobierno). The tribute collection should start one month before the end of the semester in which it was due, and the whole amount should enter the Tesorería — at the latest - two months after the end of the semester. If the due amount remained unpaid after four months, a lawsuit was filed against the Subprefecto and his guarantors [fiadores], he would be fired, and not allowed to hold any public office in the future. The tribute had to enter the Tesorería as "moneda corriente". ${ }^{26}$

The new matrículas had to include all absent peasants, and — for tributaiy purposes - peasants would only be considered absent, when the military officer in charge of recruitment had certified a peasant served in the army. Moreover, the list of absentees required the Prefecto's approval and signature before it was sent

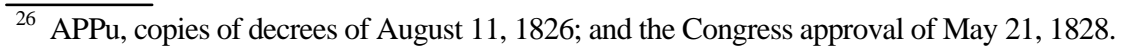


to the Ministry in Lima When there was no certifícate and/or the signature, "absent" peasants were registered as tributaries, and the Subprefecto was held responsible for the non-payment of absentee peasants. Such detailed specifications conceming soldier-peasants reveal that Bolivar's decree concerning the halt of recruitment was either short-lived or never implemented. In a trend of toughening rules, Subprefectos who had not collected the tribute due to bad harvests, or natural disasters, had to document when and with what consequences these disasters had occurred before they were exempted from fiscal responsibility. ${ }^{27}$

Such strict and precise regulations were based on fiscal necessity, but also on a current perception of the "administrative deficiencies" of those in charge of collecting tributes, especially Gobernadores and Subprefectos. In his visitto Peru's Southern departments, the Visitador de Hacienda. Don Evangelista Yrigoyen, underlined in his report that the "origin of all evils is that those entrusted with tribute collection are apathic, inert, and lenient, and that their underlings, imitating such a behavior, are but useless followers". As a consequence, he argued, outstanding debts "had been completely neglected, and everything is following apath of general decay". The Visitador suggested to replace all local powerholders, because "it would be difficult to transform those presently in charge, and make them forget their bad habits, which essentially reside in their narure". ${ }^{28}$ Even if the Visitador 's judgment was right, his proposition would have met obstacles, not only because those in power would naturally resist their dismissal, but also simply because in some places there were few people who could read and write and, thus, able to register tributaries, carry out land measurements, or report to Lima's government. ${ }^{29}$

At the level of appointments to bureaucratic positions, Lima's government had little to propose, and there was also little it could do. In spite of efforts to increase efficiency, loyalty, and order, appointments continued to be self-appointments, very much in line with what General Sucre had opted to do from the very beginning, that is, in 1825. Then, he informed the Ministro de Gobierno, that he had appointed Prefectos in Arequipa, Cusco, and Puno, but he had authorized the Prefectos to nominate all other state employees. Although Sucre recommended that persons

\footnotetext{
BN, D 11923, Funciones de los Subprefectos (2ff), 1828.

AGN, Ministerio de Hacienda, O.L. 164:1706-1713.

APPu, Comunicación del Intendente de Carabaya, Mariano Ponze al Prefecto, July 9, 1827; and November 12, 1827.
} 
with proven ability and patriotism be preferred to do the job, he knew that "factional appointments" predominated, and that this allowed for a reproduction of factionalism, the continuation of disorder, and a bad public opinion of the government. $^{30}$

Inertia and illiteracy were sources of inefficiency. However, as Sucre knew, when it carne to implement or follow state mandates, the structure of local power relations put "inertia" and "illiteracy" in a different light. Inertia and illiteracy also were mechanisms of deceit. The lawsuit filed against Subprefecto Don Pedro Miguel de Urbina, illustrates the point. ${ }^{31}$ In 1827 , the Tesorería requested that Urbina pay his tribute debts (21.507 pesos and 6 reales), otherwise he would be fired and his guarantors called in. That year, fiscal needs were especially urgent. The Pichincha Bataillon was stationed in Lampa, and the Tesorería had no other means to pay the soldiers, provide them with food, or buy fodder for its cavalry than resorting to outstanding tribute debts. But Urbina did not pay. Soldiers began deserting, assaults on peasant property followed, and fínally to avoid further disasters, the Bataillon was moved to a more promising site. In the lawsuit against him, Urbina responded that most of his debts to the Tesorería originated when he was Subprefecto in Chucuito in previous years. There-he argued - the state had decided to move him on to Lampa because of animosities with members of the local elite in Chucuito, which had also prevented him from gathering outstanding payments from "his" Gobernadores. ${ }^{32}$ Afew months later, Urbina forwarded several documents to the Tesorería (libramientos a favor del Tesoro) that showed that during his stay in Chucuito he had invested in public services an amount higher than the tribute money. ${ }^{33}$ It was probably this "transaction" which then allowed Urbina to become the Subprefecto of Lampa.

The absence of money is salient in this dialogue between the Tesorería and the Subprefecto. Money was mentioned as a debt, and later as an investment, but it never really 'existed'. What I, of course, would like to know, is why the Subprefecto unable to collect the money in Chucuito because of his quarrels and his dismissal,

30 Letter from Sucre to the Ministro de Guerra. Puno. 2/1/1825, in CDIP, tomo V, vol. 6, pp. 268-269.

31 APPu, Tesorería Pública to the Prefecto, April 13, 1827.

32 APPu, several writings and petitions from the Subprefecto Urbina to the Prefecto: February 10, 1827; February 12, 1827; March 21, 1827: August 1, 1827: October 17, 1827, documents 219-224, and 259.

33 Archivo del Palacio de Justicia de Puno (from hereon APJPu). Expediente de cobranza contra el Sor. Intendente de la Provincia de Chucuito, D. Pedro Miguel de Urbina, 1827. 
was shortly afterwards able to spend more money in public services. Two answers are likely. Either Urbina was telling the truth and paid (at least partially) for public services out of his own money, or he was cheating, pocketed the money, and when caught invented public investments (with forged documents) to cleanse his name and access the Subprefectura in Lampa. The first altemative would signal a "local identity" even at the risk of losing one's own money; the second altemative, would reveal how Subprefectos accessed tribute payments, circumvented state control, and regained a political position to repeat the cycle. Whatever really happened, the "cleansing-process" was necessary; the Subprefecto's appointment depended on the state. Beyond "legitimacy", however, Subprefectos manipulated money and arguments.

Four years later, in 1831, Urbina was still held responsible for outstanding debts, but matters were less severe. Intense pressure subsided as the state gradually relinquished portions and percentages of outstanding debts, or made monthly payments possible after recognizing that it would be impossible to ever recover even the "non-chimerical" debts. In Urbina's case, when the Treasury finally decided not to admit the public service argument and to make his guarantors pay, Urbina requested his transfer to Arequipa for health reasons, and offered to repay his debt with 400 pesos a month. The Treasury accepted his offer. Assuming that Urbina was a jerk who would fake disease to escape the fiscal grip, and pocketed the tribute money, the monthly 400 pesos he offered to pay represented a 2.0 percent monthly interest on 21.406 pesos. This was simply the cheapest capital available, or given the economic and political circumstances, the only capital available.

Between 1827 and 1835, Urbina (in Chucuito and Lampa) was not the only Subprefecto who was in trouble with the Tesorería. In Carabaya, the Tesorería attempted to involve the Subprefecto's guarantor's to recover outstanding tribute debts. Soon, the guarantors, conveniently, ran out of resources. In Azángaro, the Treasury found out with amazement that against all legal stipulations, the Subprefecto's guarantors were Indians who had but a few llamas and cows, and small plots of land. ${ }^{34}$ In Huancané, the Treasury proceeded to auction one of the

\footnotetext{
${ }^{34}$ APPu. documents 375, 372, reports from the Tesorería, 1827-28.
} 
Subprefecto's haciendas, and — not surprisingly—nobody showed up to buy it. The Treasury was forced to rent it, and the new renter was a "dependiente" of the Subprefecto.

The confrontations with the Treasury involved Puno's five Subprefectos, and illustrate the Subprefectos' success in circumventing the state's attempts to get a hold of local revenues. Subprefectos had strong reasons - fundamentally their own prívate interests - to resist state control, and they found mechanisms (including disease, transfer, and 'procedural errors') to escape state control, without jeopardizing the legitimacy provided by the state. At the end, the Tesorería quite bluntly admitted that "all recipees provided by the Tesorería die in the hands of local authorities because they alone know whathappens in the places they live". ${ }^{35}$

What the Subprefectos had "learned" in the years after independence, became an established routine in the following decades, a routine that in the wake of the Confederation (1836-1839) encountered an even weaker state.

A new wave of prosecution against Subprefectos was launched by General Nieto in 1834, and more strongly by Mariscal Santa Cruz. Santa Cruz created the Contaduría de Rezagos specifically and solely in charge of persecuting and prosecuting debtors. In 1839, the Subprefectos of Chucuito, Lampa, Huancané, Azángaro, and Ayaviri ${ }^{36}$ were ordered to leave their positions after paying the tributes for the pending semesters of Christmas 1838 and all they had so far collected for the semester of San Juan 1839. ${ }^{37}$ Some worried voices also carne from Sandia, a scarcely populated region. ${ }^{38}$ The abuses that led to their dismissal, especially in Chucuito, even merited a recrimination signed by Peru's President:

\footnotetext{
35 APPu, Relación de deudas sobre 101 deudores antiguos a 20 ramos en "cobrables e incobrables". Albeit with different arguments, as we will see. some Gobernadores learned the same strategies. In a sense there was a downward prolongation of the leamings of how to deal with an intrusive state. In 1833, the Comisión Permanente de la M. H. Junta Departamental of Puno in a letter to the Prefecto, transcribed the complaints of the priest of Pomata, concerning the abuses and default of Pomata's Gobernador, To extoit the Indians, the priest wrote, "the Gobernador did it in the ñame of the state, also to get a hold of their food supplies for small prices and then engage in commerce with them". APPu, March 27, 1833: document B-359.

${ }^{36}$ It is somewhat strange to find Ayaviri listed as a province. Ayaviri gained the status of a province only early in the twentielh ccntury.

${ }^{37}$ APPu, February 26. 1839; document B-340.

38 APPu, July 23, 1833; document 398.
} 
"I have been informed that Casiques and Gobernadores of the Province of Chucuito, trespassing all humanitarian feelings [con desprecio a la humanidad], and contravening our liberal instituüons, still use many Indians to provide them with free labor, following colonial corruption, and exert many pressures on them, to a point of putting them under the most horrendous conditions of slavery". The President ordered "that these abuses be torn out by its roots". ${ }^{39}$

However, only a few months after its establishment, the Contaduría-following the traces of the Tesorería in 1827 — recognized that it "fiad not been possible to even obtain one cent from those classified as insolvent. Now the Libros Mayores register the same amount of debts as prior to the establishment of the Contaduría". ${ }^{40}$ As a consequence, debts augmented. Following calculations forwarded by Puno's Prefecto in 1835, Puno's five provinces owed 112.284 pesos and 3 reales of "new debt". In 1840, the Ministerio de Hacienda, had a debt record for Puno in the amount of 403.175 pesos and 1 real. $^{41}$

In the meantime, the state had no money, but neither did the Departamento. In a letter to the Ministro del Tesoro, Puno's Prefecto invoked the state's help to pay for local expenses, because what he obtained from renting state lands, and the tomín were insufficient to cover expenses. Moreover, he argued, municipal resources [propios y arbitrios, mojonazgo] were so low, they were insufficient to pay for the salaries of municipal secretaries (Secretarios Municipales). ${ }^{42}$ Increasingly, the power of the state diminished, and the power of those who had direct access to Indian peasants' tribute increased. In the 1840s the Prefecturas were facing bankruptcy, and the lack of tribute funds not only affected national and departamental budgets, but also other entities and institutions, including the military (as seen above) and the church.

Since San Martin's contribución eclesiástica was only randomly implemented, the church continued to depend on state allocations. In $1830\left(?^{43}\right)$, Lima's archbishop protested:

\footnotetext{
${ }^{39}$ APPu, September 17, 1839; documents B-353, B-362, 428 and 429, Communications from Lima.

40 APPu, Relación de deudas dobre 101 deudores antiguos a 20 ramos en "cobrables e incobrables".

41 AGN. O.L. 279:361-362, Tribunal Mayor de Cuentas, Proyecto de un método para la liquidación de las cuentas pendientes en el Tribunal.

${ }^{42}$ AGN, Beneficencia de Puno.

${ }^{43}$ This is my guess, the document has no date.
} 
"I cannot omit mentioning that when the Cortes Españolas abolished the Indian tribute, from which the asignación sinodal was paid; Archbishop Dr. D. Bartolomé de las Heras [...] wrote a strong letter to the king, requesting that the missing payments be covered withtithes [masadecimal]. Since nowadays the Indians pay the same amount as the former tribute in the form oí contribución única, Your Excellency should provide that the priests get the masa sindodal from the contribución'. And, he added, that if customs were so strong, they should be even stronger in the highlands, where customs silence the laws", 44 implying that as nothing had changed the church's privileges - especially those tied into the continuation of tribute payments - be restored.

And, in a sense, the archbishop was right: there had been many new laws and attempts of reform but customs (and one should add convenience) silenced them all.

\section{SILENCING THE LAW: MATRICULAS AND GOBERNADORES}

Fraud against the state and peasants began in the very way the collection of tribute occurred. In parcialidades and ayllus, it was the Gobernadores' turn to cut out their share of the tribute. In 1839, Don Domingo Choquehuanca (1839:60-61) from Azángaro, and a member of the Indian elite, described the role of Gobernadores, Segundas, and Hilacatas in the ayllus. The Gobernadores appointed Segundas or Hilacatas, in charge of the collection in three or four ayllus, and these Indian cobradores summoned the tribute payers for a given time and in a given place. With the matrícula in hand, the Gobernador joined this assembly, and called each tributary by his name. During this meeting the Gobernador also listened to complaints. When the tribute was paid, the Gobernador handed each individual a receipt for the amount paid, and the Hilacatas or Segundas received a list of taxpayers and a copy of the receipt. Some Indians paid their tribute in one installment, those who did not would show up to mass on the following Sundays and pay the outstanding amounts to Hilacatas and Segundas, or directly to the Gobernador, who certainly also attended mass.

${ }^{44}$ Archivo Arzobispal (from hereon AA), Comunicaciones Oficiales de Curas, L 4. 
The smoothness of Choquehuanca's description contradicts peasants' experiences (described in the following section), but it lays open the interstices that made fraud possible. Fraud was a procedural fraud: receipts were not always handed out, or were forged receipts that could later be disqualified; for many reasons, an Indian may not want or be able to show up on the stipulated day or to Sunday mass, and then be subjected to persecution and imprisonment, eventually even losing his possesssions; the matrícula the Gobernador held in his hands, could be outdated or simply wrong, thus giving him the possibility to exact payments from those, or their relatives, who for reasons of age, absenteeism, sickness, or death, were exempted or no longer could pay.

Matrículas preserved in the AGN, ${ }^{45}$ carefully register tributaries' age, that is, whether they were "próximos" (under 18), or "ancianos" (over 50), in addition to "valetudinarios" (sick) and "ausentes" (absent). They also include information on family members, their place of residence (hacienda, ayllu, pueblo, isla), the status (originario or forastero), and the amount paid. In colonial times, and through "revisitas" these matrículas were updated every five years to account for demographic changes, epidemics, bad harvests, migration, etc. The growing unrest since the beginning of the nineteenth century, in addition to the high geographical mobility the wars of independence brought about, these matrículas were utterly outdated by the end of the wars. In spite of the state's orders that Subprefectos update these matrículas, and that a special "Junta de Matrícula" was created, the tributary lists show few changes between 1800 and 1853. This is evidence to the fact that matriculas are almost useless to assess demographic changes among Indian peasants in the first half of the nineteenth century, and that Subprefectos and Gobernadores had an incredible leeway in interpreting local changes their way: they could request payments from those exonerated, or exclude those subject to payment by receiving an equivalent or higher payment (bribe) from those excluded. Exclusion was just the other side of the same coin, but either way, payments in excess from those arbitran ly included and payments from those paying for exclusion was tributary money never accounted for in official statistics. Ovando

45 The Matriculas for Puno in the AGN are incomplete, and end in 1853. i.e. one year before the Indian tribute was abolished. Their "disappearance" is symptomatic in the face of the tribute exactions after 1854. Probably some Gobernadores or Subprefectos kept this register for their own records, and officially the state relinquished its control with the abolition. Thus, the "disappearance" in some way is evidence to local powerholder increased power in the provinces. 
(1985:47) synthesizes tiie typical forms ofmatrícula fraud: a. exact tributes without registering it; b. exact tributes from "reservados" and "próximos;" c. exact a higher tribute than the one stipulated for the locality and the time period; $d$. exact tribute from non-Indians; and, e. request payment for exonerations.

When occasionally complaints reached the Prefecto or even the President, and a Gobernador or a Subprefecto had to answer accusations, the most that happened was that he was given another opportunity to justify his deeds, or in the worst case, he was admonished and requested to behave better. ${ }^{46}$ In their allegations, the Gobernadores and Subprefectos often managed to turn around the argument, by showing that it was the state's fault that no new matrículas were established: the printed matrículas had not arrived in time, the Tesorería forgot to register the guarantors, or they had done everything requested from them, but thematrícula was lost. ${ }^{47}$ Until a more stringent reaction followed many years could elapse, and, in the meantime, Gobernadores and Subprefectos could be elsewhere and claim that their predecessors or successors were responsible for whatever had happened. Before the mysteries of individual responsibilities were deciphered, many more years of inquiry awaited local judges, especially if they themselves accepted bribes.

Many complaints never reached the higher echelons of the state bureaucracy. Beyond the fraud linked to registration in the matrículas, another "weapon" in the hands of Gobernadores and Subprefectos was recruitment forme anriy. Recruitment — endorsed by the state - was the "legitímate" weapon to frighten unwilling peasants. Sending a peasant as a recruit to the army was a mechanism of intimidation, a way to silence peasants on their way to denounce a Gobernador s wrongdoings and unwilling to particípate in clientelistic networks, ${ }^{48}$ pay more, pro vide them with additional services, or even to hand over their lands. ${ }^{49}$ Again, the state was there as the source of power, but it had no effective means to enforce its decrees orto control the arbitrary use of its decrees

Although it is impossible to determine how much more Indian peasants paid, some evidence suggests that "reinterpreting" matrículas was a common procedure, and it is possible to have a glimpse as to how much an unscrupulous Gobernador

\footnotetext{
46 APPu, documcnts 274, 275.

47 APPu, document 269.

48 APPu. document 265.

$49 \mathrm{APPu}$, document 270.
} 
could accumulate by resorting to these procedures. In 1826-1827, the Gobernador of Pusi (Huancané) described these same procedures when evaluating the performance of a cobrador, and he also mentioned, that this was a "common practice". As a follow up to this denunciation, the Intendente Agüirre of Huancané, inquired with the peasants in all districts of Huancané, and calculated that the extra amount peasants had paid to his predecessor for "reservados" and "muertos" amounted to 2.000 pesos. In 1829, the Indian tribute for the whole provmce of Huancané was 33.248 pesos and 6 reales that is, the extra 2.000 pesos represented approximately 6 percent of the province's tribute. Together with the legally deductible percentage for Gobernadores (2 percent), the total "accumulation" in one semester was approximately 3.500 pesos, an amount twice the president's salary that year. This was the monetaiy expression of extorsions through the matrículas, and it does not include the realms of non-monetary extorsions: labor and products. This rough estímate shows the economic advantages of apolitical position, and explains the struggles over these power positions in the ranks of local elites.

During the periods of mounting fiscal pressure from Lima around 1827 and then during the Peaivian-Bolivian Confederation, the "nonnal cycles" of extortion were interrupted and led to changes in options and attitudes. These were periods in which Gobernadores lost the monopoly of exploiting Indian peasants and, consequently, were forced to defend Indian lands, labor, and money. Only too well did Gobernadores know that they could maintain their extortions only if others competing for the same resources could be kept outside the ring. Every military recruitment order from the state, or from the Prefectura, diminished the number of tribute payers; every request for food or fodder diminished the amount of resources Gobernadores could procure for their own shack. Peasant life and production were not boundless.

The defense of Indians by some Gobernadores seldomly was an altruistic determination. By defending Indians' rights, Gobernadores rescued their command of peasant resources. Once they saved their tributarles from recruitment, they could demand additional payments as a sign of gratitude and obligation. Once they released a peasant from the pressures of a neighboring hacendado interested in a peasant's labor or land, the peasant was "indebted" to the Gobernador, or more precisely, owed eternal gratitude and obedience. 
Clashes between Gobernadores and hacendados on behalf of Indian lands transpired. Cabanilla's Gobernador, Manuel Felipe Agramonte, was especially "close" to Indian interests in his district. In 1827, he wrote a letter to Puno's Prefecto inquiring about what to do about a judicial ruling that-as he knewwas taking away communal land from aparcialidad:

"Yesterday the secretary of the judicial court carne to see me and showed me a court sentence by which I am supposed to hand the plots of Rumitia, Totorani, Cañoyo, Cañinima, and others to Da. Juana Sollana. This means that the named Mrs. Sollana will get a hold of most of the lands of a whole parcialidad of tributaries. I do not think this should happen. My community absolutely opposes this decision and I tliink that I must oppose it and join the community's protest. If I do otherwise, my Indians will think I am not defending their interests, and that for some self-interests I am not defending them but handing out their lands. So, I want to ask you, whether I could avoid this confrontation". ${ }^{50}$

Agramonte talked about "his" Indians, and wanted to help. However, the Prefecto answered (on November 27,1827) that he should follow the judicial order, and that the Indians - if they had complaints — should claim their rights in a lawsuit.

Thus, paradoxically, the Gobernadores' success to control peasant resources depended on the defense of these same resources against the state, the Prefecto, other Gobernadores, and local hacendados. Without the "ethnic legitimacy" component, the Gobernadores fulfilled a similar role to Indian curacas or caciques in the course of the colonial period (Spalding, 1985). In this role, the Gobernadores leamed lessons of downward and upward political manipulation. Upwards because they increasingly needed the repressive mechanisms an alliance with Subprefectos, Prefectos, and the state could provide; downwards because to be economically successíul they needed to access peasant resources. As for colonial caciques, this

50 "Se apersonado en este el Secretario de la Corte de Justicia con Decreto de aquella para que Yo le de pocesion como á Apoderado de Da. Juana Solíanos de las tierras de Rumitia, Totorani, Cañoyo, Cañinima, y las demas que tasan [?] sus papeles, demodo que casi de una parte ó de todas de una Parcialidad de Contribuyentes seva haser dueña la referida Sra. A mi me parece nada regular y mi [!] comunidad esta muy opuesta y Yo creo que devo en cumplimiento de mi cargo Oponerme en consorcio de ellos y por ello bea VS si puedo excimirme dela tal comicion por que me anuncia que tal bes presuman mis Yndios el que Yo por algun interes particular, lejos de defenderlos proceda a la entrega..."., APPu, document 463. 1827. 
was a dangerous game. In the first decades after Independence, Gobernadores successfully strenghtened their power, in part because the state's fiscal eye lay on the Subprefectos, and these largely depended on the Gobernadores' interdependence with hilacatas and segundas. Peasants responding in part to conviction and in part to pressure in turbulent political circumstances relied on their Gobernadores, especially when caciques were no longer around. For the time being, Gobernadores' pace of accumulation, based on the collection of tribute, accelerated. However, quickly changing perceptions altered such optimistic outlooks.

In the wake of the second wave of Subprefectos' persecution - that is, after the immediate effects of the Wars of Independence had been overcome, when demographic recovery was evident, and economic growth was palpable, many of the subtle mechanisms Gobernadores used to enhance their expanding power position surfaced and carne under scrutiny. This intricate power game is best illustrated in a detailed case involving none less than Domingo Choquehuanca, who since 1834, was the Subprefecto of Huancané. The Choquehuanca's had not supported Tupac Amaru II in 1780 (Ramos, 1982:56), and the king rewarded their loyalty by allowing them to retain power, Indians, and tributes. In 1835, the Choquenuancas supported Santa Cruz and the Confederation. Nevertheless, in 1838 the Contaduría urged him to pay his contribuciones debts dating back to 1834. ${ }^{51}$ In spite of his debts, he continued as Subprefecto until 1838, when he left to become senator for Puno. Huancané's new interim Subprefecto, Antolín Guerrero, filed suit against Choquehuanca to delimit his responsibilities from those of Choquehuanca concerning the contribuciones for the San Juan semester of 1838. The total due amount for this semester were 23.119 pesos and $51 / 2$ reales, and Choquehuanca still owed 15.755 pesos and 5 reales. Once the debt amount was established, the Contaduría decreed an embargo of Choquehuanca's hacienda Checayani and imposed a 60 percent penalty on the owed amount. Checayani's value did not cover the amount of the outstanding tribute and the penalty. The Contaduría requested that Puno's Prefecto intervene to accelerate the process, but the Prefecto remained silent out of a longstanding friendship to Choquehuanca. The Contaduría never received the property titles of Checayani; the hacienda could not be auctioned. Although the Contaduría was unsuccessful in reclaiming

51 APPu, document 13-367. 
Choquehuanca's debt, the file against him continued its legal course. The Gobernadores of Conima and Moho were called into testify against Choquehuanca and inform what liad happened to the contribuciones in their respective districts. Still, in 1839 the debts remained unpaid and the embargo on hold. By then, the Contaduría concluded — following many similar experiences - that the tribute money "liad been invested in matters alien to its purposes". ${ }^{52}$ Choquehuanca, now in Congress in Lima at this point "disappears" from the local political scenario. His "disappearance" encouraged his local enemies to speak up. Cipriano Figueroa from Ynchupalla, the former Gobernador from Huancané, Antolín Guen-ero (in 1839 the interim new Subprefecto of Huancané), and the Gobernadores from Conima and Moho, Celedonio and Paulino Machicado, all were now willing to defend themselves against Choquehuanca's allegations that it liad been them who had not delivered the due contribución amounts. Guen-ero used his interimship to align the other Gobernadores, but not for long. They, as had Choquehuanca, supported Santa Cruz. When the Confederation was defeated, the Mariscal lost power, and the Prefectos, Subprefectos, and Gobernadores he had nominated were replaced, and their properties seized. Guerrero lost his hacienda Condoraque and the hacienda Halla - of which he was the arrendatario. The owner of Halla was Mariano Figueroa, the father of the former Gobernador of Ynchupalla. ${ }^{53}$ In the new power constellation Mariano Figueroa's claims were dismissed, he lost Halla. In 1840, a new lawsuit for unpaid contribuciones for the semester of San Juan 1839 against Antolín Guerrero (the interim Subprefecto), and the new Subprefecto of Huancané, Mariano Toledo was presented in court. This time the new Prefecto interevened and threatened to go after the fiadores of both Subprefectos. When he did, it turned out that the fiadores were the former Gobernadores, the Machicado brothers, a José María Morales, and Isidro Belarde $^{54}$ In 1841, there was still another Subprefecto, Simón Aguirre. But, he too, renounced shortly after his nomination, because in Vilquechico, Antolín Guerrero, using his prestige as former interim Subprefecto and Gobernador "was able to congregate several bandits and desertors and other imbecile Indians, to steal all the fiscal money". Guerrero escaped together with Isidro Belarde, one of the prosecuted guarantors because of the debts imputed to Subprefecto Toledo. ${ }^{55}$

\footnotetext{
${ }^{52} \mathrm{APPu}$, document B-372. ${ }^{53}$ $\mathrm{APPu}$. document B-374. $54 \mathrm{APPu}$, document 461.

55 APPu. document 463.
} 
Intricate power relations revolved around the contribuciones; factional cleavages weakened or became stronger depending on the general polítical climate but more so on the building of alliances with other Gobernadores and Subprefectos, and hacienda owners, the fiadores. In this case, several Subprefectos and Gobernadores alternated in holding power positions in spite of the fact that they all supported one political leader: Santa Cruz. Accessing tribute payments and delimiting fiscal responsibilities was more important than ideological outlooks to explain provincial intraelite confrontations. The direct assault on fiscal revenues by Antolín Guerrero after his ousting describes the stakes involved.

All this did not happen in a social vacuum. Indian peasants were victims and witnesses to these fights, and observing they gained a sense of what the "new" Republican state was all about. The fears expressed by Cabanilla's Gobernador, Agramonte, that Indians perceived he was not defending their interests but his interests, was exactly what Indian peasants leamed from observing the changing faces of their Gobernadores.

\section{PEASANTS' REACTIONS}

Before, during, and after the Wars of Independence, the words 'Republic' and 'citizen' were in everyone's mouth, but the meaning of these words, and its implications, were interpreted quite differently depending on the circumstances and individual opinions. The questions about who the new citizens were, and about their rights and obligations, had a crucial impact on how power and the right to exercise power was defined. The overarching liberal notion that the sovereignty of the nation "resides with the people" ("residía en el pueblo"), the Alcalde of Azángaro patronized in 1827 was crushingly criticized by the regidores of the same municipality. The Regidores understood that looking at things that way was a "flagrant mistake" ("torpe error"), more so because of the context in which the Alcalde had made his statement: he was justifying his attempt to convene a popular court against an Intendente deemed inept. In the Regidores' opinion this was a dangerous move. One could not trust the pueblo; democracy - they claimed-was for intelligent, notforignorant people. ${ }^{56}$ Following the Regidores' call, the same year, the Prefecto

\footnotetext{
${ }^{56} \mathrm{APPu}$, document 278.
} 
of Puno deemed it necessary to intervene in defining his subaltems' obligations, duties, and convictions. They were individually invited to talk to him in his office despacho). ${ }^{57}$ Tlie contení of tliese unrecorded conversations surfaced in the events and reactions that followed.

A key message of the Prefecto was not to resort to Indian participation in defíning anything political, that is, not to build upon their support to introduce any changes. The fear of an Indian uprising emerging from their participation was latent in people's minds. Inviting Indians to particípate and making promises to tliem was equivalent 10 show Indians they had power, and empowered Indians represented a threat to an already threatened political stability.

In the district of Chamaca lived the Indians of Llallagua in three ayllus. Earlier they had sided with Tupac Amaru II. In 1827, the Gobernador of Chamaca, Macedo, used his good standing with the Llallagua Indians to reaffirm himself as Gobemador, and to oust the local priest who had complained about him to the Prefecto. The priest complained that the Gobernador had provoked an Indian uproar in the doctrina because he told Indians that priests were despots and that they only preached to become rich. Moreover, the Gobernador had told the Indians not to pay ecclesiastical fees because these fees were sheer extorsion. Indicating that "the custom to serve" had been abolished and that from now on Indians were free persons, the priest was left with no herders to take care of his sheep. To counter the priest's accusations, the Gobernador summoned the Segundas from Llallagua in his house, where they wrote and signed a letter protesting any attempt to unseat the Gobernador. Tellingly, Macedo was "retired" in May $1827 .{ }^{58}$ To resort to Indian help was considered "dangerous", and it was even worse when this participation was paralleled by a discourse on liberty, freedom, and resistance to exactions or free services. The second message of Puno's Prefecto was that the state needed the Indian tribute, even if for the sake of efficiency, justice or the ideals of citizenship had to be put aside.

In 1840, the Indians from the province of Azángaro were willing to pay 14 reales each as anticipated tribute of the Christmas semester. They gave the money to their respective Gobernadores, the Gobernadores turned the money over to the

57 APPu. document 279. 58 APPu.documents 257, 263. 
Subprefecto, who in turn entered it to the Tesorería. This payment was meant as a loan. However, soon after they had paid, the same Indians were knocking at the Subprefecto's door, day after day, to get their money back or obtain an acknowledgement of the state's debt toward them. The reason for this reaction was that in spite of their anticipated payment expressing their good will toward the state, they were requested to forward additional payments. As Indian pressure mounted, the Subprefecto requested that the Tesorería return the 4.156 pesos owed to the Indians, or that alternatively someone else become Subprefecto. He was willing to relinquish his position because he feai'ed that Indians were close to a rebellion that could cost him his life. ${ }^{59}$

Athird important message of the Prefecto was that the state's and the Tesorería's efforts to prosecute Gobernadores and Subprefectos for unpaid contributions should be handled with utmost caution. Lawsuits against local powerholders could not be hidden from the public eye, changing exactions were the peasants' thermomether of tribute-conflicts. When peasants sensed conflict their suspicions grew and their willingness to pay diminished. Moreover, they, much better than the Tesorería, knew what Gobernadores and Subprefectos did with the tributes (and all other payments) they received or managed to gain access to.

In more than one occasion Indian peasants observed how money they paid was "redirected". Funds that had benefitted them during the colonial period, were insistently drawn upon to pay for war efforts, and — as peasants knew — also sifted into the pockets of local powerholders. Bienes de comunidad and the tomin were no longer used to help Indians pay their tributes, although the rhetoric persisted. Puno's Tesorería chief administrator wrote in 1827:

"...we know for sure that by now more than 6.000 pesos are in the hands of the Gobernadores of the province of Chucuito from the tributes Indian have been paying now that the govemment has lowered their due contributions. Since these funds are meant to benefit Indians, I urge you [the Prefecto] to order the Intendente to collect these funds immediately and send them to the Tesorería". 60

59 APPu, Asillo, February 7, 1840. And other indicators of mounting pressure are in APPu, 368-380.

60 APPu, Administrador del Tesoro Público de Puno al Prefecto, 26/11/1827, B-205. Also sec, AGN, O.L. 163:1335, Estado de los ingresos que en cada año constituyen el Ramo de Hacienda en esta Tesorería de Puno y las erogaciones lijas, 21/10/1827 "...de los seis mil y mas pesos que con evidencia sabemos eccisten en poder de los gobernadores de la Provincia de Chucuito pertenecientes a los fondos 
In other words, the state had lowered the contribución as an incentive for payment The funds were urgently needed and their investment vaguely stated ("obras particulares de su particular beneficencia pública"). However, the "particular beneficencia pública", was now more a "particular beneficencia privada". During the colonial period Indians had communally owned funds (bienes de comunidad) to subsidize their mita obligations in Potosí, which in turn helped them pay their tributes to the colonial state. After Independence, some Indian communities requested that funds and tributes meant to benefit them, be redirected to build and keep up schools. In Huancané, Intendente Aguirre suggested to pay for the maintenance of its school with the rents from five communal haciendas in Ynchupalla, and one in Lipichicarca. These "communal haciendas" had been built by the Jesuits on land belonging to Indians, and their rents helped to pay the maintenance of a tailoring workshop and to cover expenses for the mita of Potosí. According to his report, the annual rent of the six haciendas in the past had been 214 pesos. By a decree issued in August 1825 the rents from these haciendas had been assigned to pay hospitals and municipal expenses [mantenimiento de los ramos de hospitales y de propios y arbitrios]. ${ }^{61}$ Then, they were used to cover war expenses ["corrían aplicados a las necesidades de la guerra"] which meant that the workshop was in decay and the teachers received no salaries. When Intendente Aguirre presented his suggestions for the schools from the six haciendas only two were left (Sivicani y Lacalaca), but they produced a 1.500 pesos annual rent and had llamas, sheep, and a few cows. Half of this amount went to the four churches in Juli, the other half went to the Tesorería. Two additional fincas, one in La Paz and another in Larecaja, which had belonged to the same ecclesiastical jurisdication before the wars, now with the creation of the national boundary between Peru and Bolivia had an even more uncertain destiny, and no one knew in which shape they were. ${ }^{62}$ To rescue some Indian rights Intendente Aguirre invoked colonial legislation (Libro Sexto de la Recopilacion de Indias, titulo 4to., ley 13) by which "la plata que resultase de los vienes, censos y renta de comunidad, se ha de gastar solamente en lo que se dirijiese al descanso y alivio de los indios, y convirtiese en su probecho y utilidad". Now, whatever was left from the rents of these communal haciendas went to the

que aquellos Indígenas van depositando con la rebaja de su Contribucion para las obras particulares de su particular beneficencia publica, sírvase V.S. mandar que el Sor. Intendente los colecte y remita sin la mas leve demora...".

${ }^{61} \mathrm{APPu}$, document B-270.

${ }^{62}$ APPu. Pedro Miguel de Urbina. intendente de Chucuito al Prefecto. Chucuito, 01/08/1825. 
church, and a former Gobernador kept the money obtained from renting pasture land [rentas de yerbajes] which earlier had been used to pay the teacher. The fincas of Pasana-Ccollo and Guando, and the pastures from Hanccoamani and Guaicuyo, located in Lampa, still produced an annual rent of 490 pesos.

Aguirre's insistence on keeping Indian lands and produce for the benefit of Indians, reinforced the idea that the state should not allow these funds to be "redirected", and this, as seen above, sometimes was simply another argument to withhold funds from the state. Similar claims carne from Gobernador Pablo Pimentel in Orurillo in $1840 .{ }^{63}$ With some notable exceptions, ${ }^{64}$ the wars and the various and often contradictory decrees dismantled traditional Indian rights. Indians watched their schools and workshops close down for the lack of funds. Fund reallocation often occurred in the name of a war, and was part of the initial experiences of the Indian popuíation vis a vis the new Republican state that fought wars that never seemed to end.

Parallel to these observations, Indians also watched the quick turnover of their Gobernadores. Following the whims of the civil wars that followed the Wars of Independence, more than once, Indian peasants were requested to pay their tribute to each new incoming Gobernador. Often, they had already paid the due semester amount to the predecessor, or so they claimed. The familiarity that underlied the obligation to pay tribute was disrupted by rapid face changes.

In February 1839, one month before the Santa Cruz's Confederacion was defeated, the Estado Sud-Peruano requested that the Gobernadores collect tribute from Indians due only in July. The anticipated tribute payments ran against custom and possibility, and foreseeably, the Gobernadores could only sent in portions of the tribute from their districts. When, one month later, new Gobernadores carne to power they immediately set out to collect tribute. However, Indians reminded them that a portion of the due tribute had been already paid to their predecessors,

\footnotetext{
63 APPu. Informe de Pablo Pimentel, gobernador de Orurillo al Prefecto. Orurillo, 14/04/1840.

${ }^{64}$ On February 9, 1835. the Presidencia de la Honorable Municipalidad of the city of Lampa informed the Prefecto that all materials for the girls" school had been paid for with bienes de comunidad administered by Anselmo Arze. Since at least 1833 the Prefectura had helped toward paying the costos of maintaining the school. and in 1835 the municipality requested that the Prefectura continue doing so. APPu, 1835:470. As the school was located in the city of Lampa, 1 suspect that the girls attending the school were the daughters of the vecinos, not of Indians.
} 
and only paid what they saw fit, "porque son los únicos que ha podido reunirse a causa de que han adelantado a mi antecesor segun me indican". ${ }^{65}$ The instability-argument-obvious to everyone — was used by peasants and Gobernadores to skip payments to the state.

In a last effort to create the Confederación, Santa Cruz attempted to massively mobilize the Indian population in the South. ${ }^{66}$ The General en Jefe del Ejército del Sur requested help from caciques and Gobernadores to form montoneras in each pueblo to repel Bolivian military incursions. Indians enrolled in the montoneras would be exempted from tribute payments during the war, and could keep whatever they took away from the Bolivian army. Those Indians who stayed in their pueblos were requested to hide their cattle in order to avoid that these resources fall into Bolivianhands. ${ }^{67}$ This active involvement made tribute collection even more difficult and blurred. As during the Wars of Independence, peasant resources were consumed but went unpaid. By April 1839, there were no more cabalgaduras: '"despues de la consumación que han ocacionado los transitos frecuentes del Ejercito inbasor Boliviano [y...] en la actualidad las tropas Nacionales hasen uso de multitud de Bagages con que de un pueblo a otro se les auxilia en clase de carga consejil.". Even worse, animals taken from peasants were lost or simply not returned to their owners. This led to "discredit the goverment and the resentment against the Peruvian cause, because the Indians are the most narrowminded of all, as they are only interested in their own private interests". 68

In spite of Indians' defense of their prívate interests, some Gobernadores managed to get hold of peasant resources. In 1839, the Indians of Llalli complained against their Gobernador, Don Isidro Mendoza:

"...nos oprime en tal estremo de esponernos a notables resultados [...] Con motivo de ser arrendatarios en una Hacienda nominada Chacha [ubicada en las "goteras" de los linderos de la parcialidad] con el disfraz de daños de sus pastos toma

\footnotetext{
65 APPu, documcnt B-373.

66 CDIR t. XVI. Archivo Riva Agüero, p.894. Carta de Santa Cruz a Riva Agüero. Cusco, 13/09/1838. "Dar impulso a la guerra popular que prepara nuestros triunfos".

6 APPu. General del Ejército del Sur al Subprcfecto de Lampa. Lampa, 01/12/1841.

68 APPu. 05/04/1839. ["causando el descredito del Govierno y la odiosidad de la causa del Peru, porque la clase indígena mas mesquina que otra cualquiera parece que no tiene otro idolo que el de su interes particular"].
} 
nuestros ganados, los obejunos, los señala, con la que acostumbra interpolar estas en su tropa [y] son irreclamables; los Bacunos, depositandolos en el interior de su Hacienda y no pagando los dueños dos reales por cabesa no Salen de alli; los caballos, y demas bestias son tomadas por el o su encargado con esta patraña para su servicio de modo que arruinadas las bota". ${ }^{69}$

Amidst the war, this Gobernador was not taking animals from peasants to support a war. The animals augmented his own prívate herd, and the money the Gobernador obtained from "kidnapping" Indians' beasts went into his pockets. By denouncing the Gobernador, the índians from Llalli showed the "narrow-mindedness" of local powerholders, an attitude that had forced them to abandon their pueblo. To prove their accusations, the índians of Llalli requested to file a lawsuit against the Gobernador. We do not know what happened in this case, but in other places such indictments led to the Gobernador's replacement. In a similar complaint, the índians from Pucará, ousted their Gobernador, Don Manuel Víctor Zenon Ramos, "por los abusos, estafas, y tropelías que ha cometido en su destino". ${ }^{70}$

During periods of war, when the pressures on peasant resources mounted and the state "carne closer" the tensions between peasants and Gobernadores increased, and gave peasants an opportunity to get rid of greedy Gobernadores often by showing that when it carne to demonstrate patriotism or loyalty peasants were less "narrowminded" than Gobernadores or Subprefectos. Santa Cruz understood the message and noted that, montoneras and guerrilla leaders lacked the enthusiasm he had observed among them during the Wars of Independence, when often these same people had fought against Spaniards. ${ }^{71}$ During the years of the Confederación, a process of selection in the ranks of local powerholders occurred, depending on the ability a Gobernador had to realign himself with the changing political winds (together with Subprefectos and Prefectos), and/or with Iridian peasants. Power was manipulated — with unequal success — in both directions. The initial closeness between Gobernadores and índians was eroded by the war, and by índians observing that the war provided their Gobernadores with a possibility of personal enrichment. As aconsequence, Gobernadores could rely less on índians to assert their positions and gain income, and had to rely more on coercion. To

\footnotetext{
${ }_{70}$ APPu. Los indios de Llalli contra el gobernador. 06/1839; 307.

70 APPu. Francisco Montesinos, Juzgado de Primer Instancia al Prefecto. 11/11/1839.

71 DIP, t. XVI. Archivo Riva Agüero. Comunicación de Santa Cruz a Riva Agüero. Cusco, 29/09/1838.
} 
exert coercion the Gobernadores needed to turn to the upper echelons of state power, the Subprefectos and Prefectos, especially when military or police intervention was required.

Increasingly Indians resisted to pay. After three years of war during the Confederación, the Indians from Huancané who had been willing to help transport "pertrechos, panes, zapatos, cebada en grano, y otros" during the fight against the Chileans, insistently requested that their 31 donkeys be returned to them, and resisted continuing to pay the contribución ["...aun la contribución no quieren pagar".]. Resistance to pay and the devastation brought about by the war made it difficult for Gobernadores to collect the contribución. During the Wars of Independence there had been difficulties as well; what was new one decade later was Indians' resistance to pay. ${ }^{72}$ This was a frightening message for those who had greatly benefitted from the Indian tribute and believed that involving Indians in anything political was a threat to political stability.

The clearer it became that the Confederación was an unviable political and military undertaking, the more the Gobernadores retreated from the political scenario. To avoid the mounting requests for resources and money they were increasingly unable (or unwilling) to provide, the Gobemadores abandoned their pueblos. The "enemies" knew that these positions were crucial and quickly sought a repíacement to get a hold of tribute payments. The new Gobernadores had even less support from Indians, and often did not know local conditions. As one observer put it, Gobernadores [mandatarios] were now "algunos mozos insignificantes", rejected by Indians and vecinos. ${ }^{73}$ Political positions lost credence, and many displaced or hiding Gobernadores survived the war by continuing with their commercial businesses, but without the benefit of their direct access to capital,the contribución. In October 1840, Chucuito s Subprefecto, Joaquín Lizardo, commented that

\footnotetext{
72 Already in 1835 Azangaro's Subprefecto, D. Mariano Joaquín Urviola, in a letter to the Prefecto informed that he had not reccived contribucion payments from the Gobernadores in his province, "because of the great misery and poverty of the Indians in this province". And he added that "he could not biame the Gobernadores because all efforts only led to very small payments*'. APPu, Subprefecto al Prefecto, Azángaro, 14/12/1835: $380 . .$. "no puedo culpar a los Gobernadores por que bien veo que estos en vano se esfuerzan puesto que los cobradores haciendo los mayores sacrificios contribuyen en las mas pequeñas sumas".

${ }^{73}$ BN, D 1714, Proyecto de operaciones de una tropa ligera, que se puede hacer por las inmediaciones de Vilque, Cabanilla y Lampa, presentado al Sor. General. Arequipa. 14/02/1842. Some vecinos ventured to take some "mozos insignifcantes" prisoner..." ban capturados por los vecinos sin que puedan remediarlo".
} 
síndicos, priests, and Gobernadores "far from doing their job as mandated by law, have completely retreated using banal pretexts, have gone far away, or are dedicated to their own commercial speculations". ${ }^{74}$

In a sense then, peasants' resistance to pay tribute based on the recognition of their misuse of it, eliminated the local representatives of the state. Reports on local conditions portrayed a general decay in Puno:

"...today everything is in ruins because the war left the fundos without laborers, the city workshops are empty, and those who are still there do not pay. Nobody is paying anything". ${ }^{75}$

Lack of labor and money was the message summed up by the Ministerio de Hacienda when interpreting the many petitions and descriptions coming from the provinces. Capital became extremely expensive, "las usuras han subido a un punto el mas escandaloso, solo buenos para sorberse los ultimos restos que han quedado en mano de uno que otro propietario". ${ }^{76}$

The church also lamented economic disaster and — more generally - the moral consequences of the war. ${ }^{77}$ In answering a request of Lima's Archbishop to make an inventory of all ecclesiastical possessions around the mid-1840s, local informants revealed the deplorable conditions that had resulted from the war:

74 APPu. Subprefecto de Chucuito Joaquín Lizardo al Prefecto. 02/10/1840: 428... "lejos de dedicarse a llenar los mandatos que les consigna la ley, se retraen absolutamente, ya eludiéndose con pretextos infinitos ya ausentandose a largas distancias, e ya en fin por contraerse esclusivamenle a sus especulaciones comerciales".

75 AGN. Ministerio de Hacienda. O.L. 282:1-25a. expedientes y solicitudes. Expedientes Civiles. 1840. "Hoy todo esta reducido a ruina; pues los fundos rústicos, sobre las calamidades producidas por tanta guerra desoladora, ya casi carecen de brazos para su labor. Los urbanos que por desgracia no se hallan en el mejor lugar de la ciudad, se mantienen vacíos, y si ocupados no pagan, y estan sugetos a litigios por su naturaleza no es la menor desgracia; y, por ultimo, principales impuestos en los fondos publicos, y a mutuo en particulares que todos han fracasado, y lodo junto presenta un cuadro bien lastimoso".

76 AGN., ibid. Comments forwarded by Francisco Moreyra y Matute to the Ministro de Hacienda in 1840, reveal the meaning of the local decay for the Peruvian state: "Por fin se ha perdido ya el equilibrio que mantenia el orden y el concierto, y en que consiste la riqueza de los estados que es el valor del dinero y el producto de las propiedades, desnivelandose de tal modo, que ya falta esa armonía y justa proporcion, que precisamente arrastra consigo la ruina y destruccion general".

77 AA, Comunicaciones de Curas, L3, 1712-1843. 
" In the wake of the revolution and amidst great disorder many usurpations have occurred, and the people who enjoy properties that do not rightfully belong to them are allowed to keep them, because of the many changes the country has suffered, the little consistency of prevailing laws, and the general uproar. All this has slowly made reality unrecognizable [and] has completely perverted any sentiments of honesty". ${ }^{78}$

Disorder, poverty, and lack of resources were rampant. But all this together had changed local power constellations, justified the abolition of all reform attempts, and maintained the tribute payments. Had Paulding remained in Puno all these years, he would have understood Gulcán's Gobernador s resilience to accept his money.

78 AA, Comunicaciones de Curas. L3. 1712-1843/1846. "en el curso de la rebolucion y en medio de los desordenes producidos por el desarreglo de la rebolucion se han efectuado muchas usurpaciones, y las personas que disfrutan de bienes ágenos cuentan con la permanencia de sus ilegitimas adquisiciones por que las mutaciones del pais. la poca consistencia de sus Leyes, y la agitacion de los espíritus, al paso que han ido envolviendo las cosas en tinieblas impenetrables han avivado [y] pervertido los sentimientos de honradez". 
FRONTERAS • No. 4 / VOL. 4 / 1999•

\section{B1BLIOGRAPHY}

Assadourian, Sempat C,"The Colonial Economy: The Transfer of the European System of Production to New Spain and Perú", Journal of Latín American Studies, vol. 24:55-68,1992.

Basadre, Jorge, Historia de la República del Peru, esp. vol. II, ch. 28 "Las comunicaciones, los transportes y la economía hasta 1841", 1961 (1969).

Jacobsen, Nils, "Cycles and Booms in Latín American Export Agriculture. The Example of Southern Peru"s Livestock Economy", Fernand Brandel Review, VII, 3:443-507, 1984.

n. d., "Free Trade, Regional Élites and the Internal Market in Southern Peru, 1895-1932", (paper).

Mirages of 'Transition. The Peruvian Altiplano, 1780-1930, Berkeley, Los Angeles, London:University of California Press, 1993 (1982).

García Calderón, Francisco, Diccionario de la Legislación Peruana, Lima; París, Librería Laroque, jeune, 1879.

Mailon, Florencia, The Defense of Commimity in Peru s Central Highland: Peasant Struggle and Capitalist Transition: 1860-1940, Princeton; Princeton University Press, 1983.

Manrique, Nelson, Mercado interno y región. La sierra central, 1820-1930, Lima, DESCO, 1987.

Manrique, Nelson y Burga, Manuel, "Rasgos fundamentales de la historia agraria peruana, siglos XVl-XX", paper SEPIA, Lima, 1989.

Mitre, Antonio, El monedero de los Andes. Región económicaymoneda boliviana en el siglo XIX, La Paz, HISBOL, 1986.

Piel, Jean, "The Place of the Peasantry in the National Life of Peru in the Nineteenth Century", Past and Presen!, no. 46:108-134,1970.

Crise agraire et conscience créole au Pérou, Toulouse, Centre National de la Recherche Scientifique. Centre Regional de Publications de Toulouse. Amérique Latin - Pays Ibériques, 1982. 


\section{REINVENTING OLDPOWER}

Platt, Tristan, "Entre Ch'axwa y Muxsa. Para una historia del pensamiento político aymara", Therese Bouysse-Cassagne et. al., Tres reflexiones sobre el pensamiento andino, La Paz, HISBOL, 1987.

"Producción, tecnología y trabajo en la Rivera de Potosí durante la república temprana", paper Sucre, 1994.

Ramos Zambrano, Augusto, Puno en la rebelión de Túpac Amara, 1982.

Romero, Emilio, Monografía del. Departamento de Puno, Lima, Imp. Torres Aguirre, 1928.

Spalding, Karen, "Exploitation as an Economic System: The State and the Extraction of Surplus in Colonial Peru", mss.

Stern, Steve (ed.), "The Social Significance of Judicial Institutions in an Exploitative Society: Huamanga, Peru, 1570-1640", George A. Collier, Renato I. Rosaldo and John D. Wirth, The Inca an Aztec States, 1400-1800, Academic Press, 1982.

Resistance, Rebellion, and Consciousness in the Andean Peasant World, 18th to 20 Centuries, Madison, Wisconsin University Press, 1987.

Te Paske, John J. "La crisis del siglo XVI11 en el Virreinato del Perú", Bernardo García Martínez et. al. (eds.), Historia y Sociedad en el mando de habla española (homenaje a José Miranda), México, El Colegio de México, 1970.

"The Fiscal Structure of Upper Peru and the Financing of Empire", Karen Spalding (ed.), Essays in the Política/, Economic and Social History of Colonial Latin America, Nevvark, D.E., 1982.

Thurner, Mark, "Andean Peasant Politics: Regional Society, and the Nation-State (Ancash 1854-1920)", mss., 1988.

"From Two Nations to One Divided: Postcolonial Nation - Buildingand Ethnic Domination in Andean Peru (Huaylas, ca. 1780-1900)", paper AAA Chicago, 1991.

Walker, Charles (comp.), Entre la retórica y la insurgencia: Las ideas y los movimientos sociales en los Andes, siglo XVIII, Cusco:Centro de Estudios Regionales Andinos "Bartolomé de las Casas", 1996.

Veliz, Claudio, 77 the Centralist Tradition in Latin America, Princeton, N.J.:Princeton University Press, 1980. 